\title{
Production and characterization of pectinase enzyme from Penicillium chrysogenum
}

\author{
A. Rasheedha Banu, M. Kalpana Devi, G. R. Gnanaprabhal, B. V. Pradeep and M. Palaniswamy \\ Department of Microbiology, Karpagam University, Coimbatore - 641 021, Tamil Nadu, India \\ m.palaniswamy@gmail.com
}

\begin{abstract}
Ten moulds isolated from municipal waste soil sample were screened for pectinolytic enzyme production when grown on pectin containing (YPSS) solid media. Penicillium chrysogenum was selected based on clearance zones and pectinase enzyme production was carried out in submerged fermentation. Enzyme production by Penicillium chrysogenum was higher at $\mathrm{pH} 6.5$ and a temperature of $35^{\circ} \mathrm{C}$ using sucrose and ammonium per sulphate as carbon source and nitrogen source, respectively. The maximal activity of $P$. chrysogenum pectinase was at $50^{\circ} \mathrm{C}, \mathrm{pH} 6.5$ and was thermostable up to $40^{\circ} \mathrm{C} . \mathrm{MgCl}_{2}$ and $\mathrm{CaCl}_{2}$ ions had little effect on pectinase activity. $\mathrm{K}_{\mathrm{m}}$ and $\mathrm{V}_{\max }$ values were 1.0 $\mathrm{mg} / \mathrm{mL}$ and $85 \mathrm{U} / \mathrm{mg}$ protein, respectively and an apparent molecular weight of $31 \mathrm{kDa}$ on SDS-PAGE.
\end{abstract}

Keywords: Penicillium chrysogenum; submerged fermentation, pectinase.

Introduction

The utilization of microbial enzymes has found broad technological application in different industrial processes. Among the various enzymes commercialized many are products of fermentation of filamentous fungi (Piccolivalle et al., 2001). The genus Penicillium is world wide known for production of secondary metabolites and extracellular enzymes of commercial value, including pectinases.

Pectinase are now an integral part of juice and textile industries (Kashyap et al., 2001) such as maceration of tea leaves (Angayarkanni et al., 2002); processing of cotton fabric (Solbak et al., 2005) as well as in various biotechnological applications (Alkorta et al., 1998, Jacob \& Prema, 2006). The filamentous fungi are most often used in the commercial production of pectinases. Microbial production of pectinases has been extensively studied (Kashyap et al., 2001, Torres et al., 2006); actinomycetes (Bruhlmann et al., 1994); Aspergillus flavus (Mellon \& Cotty, 2004); Aspergillus sp. (Angayarkanni et al., 2002); Penicilluim italicum (Alana et al., 1990); Penicillium viridicatum RFC3 (Silva et al., 2002); Penicillium roqueforti (Pericin et al., 2007); Penicillium expansum (Cardoso et al., 2007) and Pectolytic moulds (Fawole \& Odunfa, 1992).

New enzymes for use in commercial applications with desirable biochemical and physico-chemical characteristics and a low cost production have been the focus of much research (Silva et al., 2002; Malvessi \& Silveira, 2004; Phutela et al., 2005). Enzyme breakdown of the biomolecules depends up on the type of enzyme, application, temperature, incubation time, agitation, concentration, $\mathrm{pH}$ and use of different enzyme preparations (Dominguez et al., 1994; Chadha et al., 2003). In this context, the objective of the present study was to produce pectinolytic enzymes by a newly isolated strain of Penicillium chrysogenum by submerged fermentation and process evaluation. Furthermore, the physico-chemical characteristics of the purified enzymes are also presented.

\section{Materials and methods}

Isolation of fungal species

The soil fungi were isolated from municipal solid waste collected from Coimbatore, Tamil Nadu, India. Isolation medium of following composition, g/L (Pectin, 10; sucrose, 10; tryptone, 3; yeast extract, $2 ; \mathrm{KCl}, 0.5$; $\left.\mathrm{MgSO}_{4} .7 \mathrm{H}_{2} \mathrm{O}, 0.5 ; \mathrm{MnSO}_{4.5} \mathrm{H}_{2} \mathrm{O}, 0.01 ;\left(\mathrm{NH}_{4}\right)_{2} \mathrm{SO}_{4}, 2\right)$ supplemented with mineral salt solution of composition $\mathrm{g} / 100 \mathrm{~mL}\left(\mathrm{CuSO}_{4} .5 \mathrm{H}_{2} \mathrm{O}, 0.04 ; \mathrm{FeSO}_{4}, 0.08 ; \mathrm{Na}_{2} \mathrm{MoO}_{4}\right.$, $\left.0.08 ; \mathrm{ZnSO}_{4}, 0.8 ; \mathrm{Na}_{2} \mathrm{~B}_{4} \mathrm{O}_{7}, 0.004, \mathrm{MnSO}_{4}, 0.008\right), \mathrm{pH}$ 5.5-6.0 was used. To the above medium, ampillicin (100 $\mathrm{mg} / \mathrm{l})$ was added to restrict bacterial growth. The inoculated plates were incubated at $50^{\circ} \mathrm{C}$ for 5-7 days. The cultures were further purified by sub-culturing on YPSS (Yeast soluble starch agar) medium having composition, $\mathrm{g} \mathrm{I}^{-1}$ (starch, 15; yeast extract, 0.4; $\mathrm{K}_{2} \mathrm{HPO}_{4}$, 0.23; $\mathrm{KH}_{2} \mathrm{PO}_{4}, 0.2 ; \mathrm{MgSO}_{4} .7 \mathrm{H}_{2} \mathrm{O}, 0.05$; citric acid, 0.052; $\mathrm{pH}$ 5.5-6). Identification of the genus was based on morphological and biochemical characteristics (Phutela et al., 2005).

Screening of soil fungal isolates for pectinolytic activity

A total of ten isolates from soil were assayed for polygalacturonase (PG) activity using pectin containing agar medium. Culture plates with pectin-containing agarose were inoculated with each isolate and incubated for $3-5$ days at $31^{\circ} \mathrm{C}$. Isolates were replicated 2 to 3 times and tests were performed twice. After incubation, plates were stained with aqueous $0.05 \%$ ruthenium red solution for $1 \mathrm{~h}$ and rinsed with deionised water. Cultures expressing pectinase activity exhibited a clear zone around the margins of the colony. Isolates without a clear zone usually exhibited a ring of intense staining around the colony.

\section{Enzyme production by submerged fermentation}

The fungal culture was used to produce pectinase enzyme using liquid medium $(\mathrm{g} / \mathrm{L})$ citrus pectin, 10; $\left(\mathrm{NH}_{4}\right)_{2} \mathrm{SO}_{4}, 1.4 ; \mathrm{K}_{2} \mathrm{HPO}_{4}, 6 ; \mathrm{KH}_{2} \mathrm{PO}_{4}, 2 ; \mathrm{MgSO}_{4} .7 \mathrm{H}_{2} \mathrm{O}$,
Research article

CIndian Society for Education and Environment (iSee)
"Pectinase from P.crysogenum"

http://www.indjst.org
Banu et al. Indian J.Sci.Technol. 
Indian Journal of Science and Technology
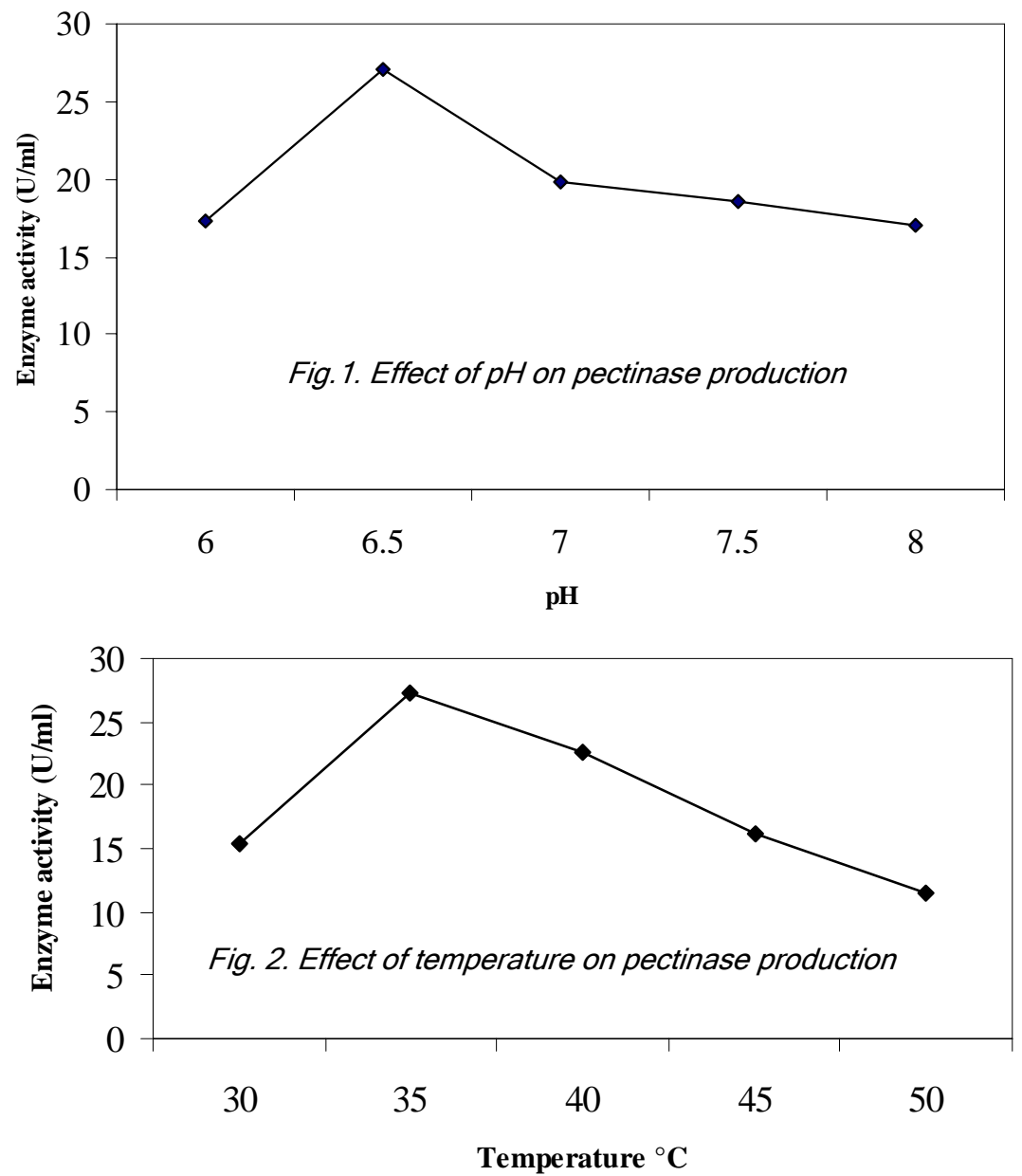

Vol. 3 No. 4 (Apr. 2010)

ISSN: 0974- 6846

sucrose \& starch) and nitrogen sources (Ammonium persulfate, Ammonium nitrate, Ammonium chloride, Peptone \& Ammonium oxalate)], on selected pectinase enzyme production was studied.

Polygalacturonase enzyme assay

The polygalacturonase activity was determined by measuring the amount of reducing substances liberated from citrus pectin. The reaction mixture consisted of substrate buffer $(0.125 \mathrm{~g}$ citrus pectin dissolved in $25 \mathrm{~mL}$ of $0.2 \mathrm{M}$ sodium citrate buffer, $\mathrm{pH} 6.5$ ) and enzyme solution $(0.5 \mathrm{~mL})$. This mixture was incubated at $37^{\circ} \mathrm{C}$ for $30 \mathrm{~min}$., heated in a boiling water bath for $5 \mathrm{~min}$ and the reaction was stopped by using $3 \mathrm{~mL}$ of DNS reagent. The absorbance was read at $570 \mathrm{~nm}$. One unit of enzyme activity $(U)$ was defined as $1 \mu \mathrm{mol}$ of galacturonic acid released per min (Silva et al., 2002).

Protein content

Protein content was determined by the method of Lowry et al., (1951), using Bovine Serum Albumin (BSA) as standard.

Enzyme purification

The crude enzyme filtrate was dialyzed and clear supernatant $(200 \mathrm{~mL})$ was mixed with three volumes of cold ethanol and kept undisrupted for overnight at $4^{\circ} \mathrm{C}$. The resulting precipitate was collected by centrifugation at $9,000 \times \mathrm{g}$ for $30 \mathrm{~min}$ at $4^{\circ} \mathrm{C}$. The precipitate was dissolved in $10 \mathrm{~mL}$ of sodium citrate buffer $(\mathrm{pH}$

$0.1 ; \mathrm{pH}, 6)$. Fermentation was carried out in $500 \mathrm{~mL}$ Erlenmeyer flask containing $250 \mathrm{~mL}$ of growth medium with $10 \%$ inoculum $\left(10^{6}\right.$ spores $\left./ \mathrm{mL}\right)$ and incubated at $30^{\circ} \mathrm{C}$ under shaking conditions $(175 \mathrm{rpm})$ for 5 days (Angayarkanni et al., 2002). The biomass was separated by centrifugation at $10,000 \times \mathrm{g}$ for $15 \mathrm{~min}$ at $4^{\circ} \mathrm{C}$. The supernatant was used to evaluate the polygalacturonase enzyme activity.

\section{Culture conditions}

The cultural conditions $[\mathrm{pH}(6-8)$, temperature (30$50^{\circ} \mathrm{C}$ ), different carbon (glucose, galactose, mannitol,

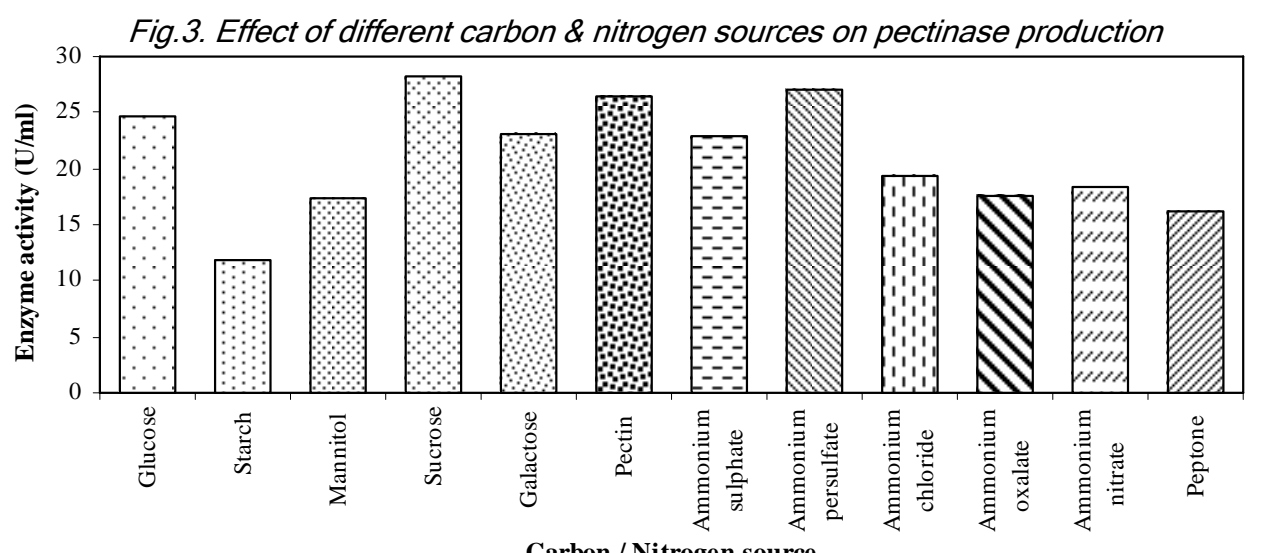

6.5) and dialyzed against distilled water. For further purification, the dialyzed sample was lyophilized to $5 \mathrm{~mL}$ and passed through Sephadex G-100 column (1.5 x 45 $\mathrm{cm})$ equilibrated with sodium citrate buffer $(\mathrm{pH} \mathrm{6.5)}$ and eluted with the same buffer. About 20 fractions were collected at a rate of $10 \mathrm{~mL} / \mathrm{h}$. The fraction of the enzyme that showed highest enzyme activity was then pooled and used for characterization (Angayarkanni et al., 2002)

Enzyme characterization

The enzyme $P G$ activity was determined at $35^{\circ} \mathrm{C}$ in different $\mathrm{pH}$ using acetate $(\mathrm{pH} 4.0-$ $5.0)$, citrate $(\mathrm{pH} 5.0-6.0)$, sodium citrate $(\mathrm{pH}$ 6.0-7.0) and Tris- $\mathrm{HCl}$ $(\mathrm{pH} 7.0-8.0)$ as buffers. The optimum temperature was assayed by incubating each reaction mixtures at $20-80^{\circ} \mathrm{C}$ and its thermo stability. The reaction speed $V_{\max }$ and $\mathrm{K}_{\mathrm{m}}$ were determined for the enzyme by varying the substrate concentration from $2-20 \mathrm{mg} / \mathrm{mL}$ and plotting substrate/velocity as function of substrate concentration (Line-Weaver \& Burk, 1934).
Research article

CIndian Society for Education and Environment (iSee)
"Pectinase from P.crysogenum" http://www.indjst.org
Banu et al. Indian J.Sci.Technol. 
For determination of the influence of $\mathrm{CaCl}_{2}$, $\mathrm{CuSO}_{4}, \mathrm{CoCl}_{2}, \mathrm{HgCl}_{2}$, $\mathrm{ZnCl}_{2}, \quad \mathrm{MgCl}_{2} \quad$ EDTA and $\mathrm{BaCl}_{2}$ on $P G$ activity, the salts were added to the reaction mixture $(5 \mathrm{mM})$, and the enzyme activity was determined as described above. SDS-PAGE of protein samples was performed using $12 \%$ gel. After migration protein bands were stained with Coomassive Brilliant Blue (CBB) (Laemmli, 1970).

Results and discussion Screening of isolates

Ten fungal species isolated from municipal solid waste material and morphological characteristics were examined. Fungal cultures were further screened by yeast soluble starch agar plate method and the zone of clearance was calculated. Penicillium chrysogenum and Aspergillus niger cultures had a zone of clearance above $3 \mathrm{~mm}, A$. alacatus, $A$. flavus, $A$. fumigatus, $A$. oryzae and $P$. italicum cultures had a zone of clearance between 1 and $2 \mathrm{~mm}$ and Rhizopus oryzae, Rhizopus sp. and Mucor $s p$. isolates had a

\begin{tabular}{|l|c|}
\multicolumn{2}{c}{ Table 2. Properties of pectinase } \\
\hline Properties & P. chrysogenum \\
\hline Optimum pH & 6.5 \\
\hline Optimum temp. $\left({ }^{\circ} \mathrm{C}\right)$ & 50 \\
\hline Thermostability $(\mathrm{min})$ & 60 \\
\hline $\mathrm{V}_{\max }(\mathrm{U} / \mathrm{mg}$ protein $)$ & 85 \\
\hline $\mathrm{K}_{\mathrm{m}}(\mathrm{mg} / \mathrm{mL})$ & 1.0 \\
\hline Molecular wt $(\mathrm{kDa})$ & 31 \\
\hline
\end{tabular}

Table 2. Properties of pectinase

\begin{tabular}{c|c|c|c|}
\hline $\begin{array}{c}\text { Total } \\
\text { activity } \\
(U)\end{array}$ & $\begin{array}{c}\text { Specific } \\
\text { activity } \\
(\mathrm{U} / \mathrm{mg})\end{array}$ & $\begin{array}{c}\text { Purification } \\
\text { (fold) }\end{array}$ & $\begin{array}{c}\text { Recovery } \\
(\%)\end{array}$ \\
\hline 3818 & 7.30 & 1.0 & 100 \\
\hline 2205 & 32.53 & 4.45 & 57.77 \\
\hline 918 & 145.84 & 17.24 & 48.12 \\
\hline
\end{tabular}

Table 3. Effect of metal ions \& inhibitors (5 mM) on pectinase activity

\begin{tabular}{|c|c|}
\hline $\begin{array}{c}\text { Metal } \\
\text { ions }\end{array}$ & $\begin{array}{c}\text { Residual } \\
\text { activity (\%) }\end{array}$ \\
\hline None & 100 \\
\hline $\mathrm{CaCl}_{2}$ & 103.56 \\
\hline $\mathrm{MgCl}_{2}$ & 73.44 \\
\hline $\mathrm{ZnCl}_{2}$ & 83.79 \\
\hline $\mathrm{HgCl}_{2}$ & 41.23 \\
\hline $\mathrm{CoCl}_{2}$ & 41.50 \\
\hline $\mathrm{CuSO}_{4}$ & 40.50 \\
\hline $\mathrm{BaCl}_{2}$ & 60.53 \\
\hline EDTA & 61.35 \\
\hline
\end{tabular}
produced by $P$. griseoroseum does not appear to be influenced by concentrations of sucrose used or by the free glucose in the medium.

Of the different nitrogen sources used, ammonium persulphate has enhanced the production of $P$. chrysogenum pectinase (Fig. 3). Phutela et al., (2005) reported that $\left(\mathrm{NH}_{4}\right)_{2} \mathrm{SO}_{4}$ stimulated pectinase production, as in its absence fungus displayed a slight proteolytic activity and did not produce extracellular pectinases.

\section{Enzyme purification}

Pectinase enzyme was partially purified zone of clearance below $1 \mathrm{~mm}$ or no clearance zone around the colonies (data not shown). On the basis of screening method, the isolate Penicillium chrysogenum found to be a potential source of pectinolytic enzyme. This culture was used for optimization of pectinase production using submerged fermentation.

\section{Optimization of cultural conditions}

The $\mathrm{pH}$ of the cultivation medium is an important factor in the production of pectinases for it influences the sort and content of those enzymes produced by fungus. The strong effect of $\mathrm{pH}$ on the production endo $\mathrm{PG}$ was clearly observed in flask cultures, were $\mathrm{pH}$ value 6-8 was tested (Fig. 1). The maximum PG activity occurred with an initial $\mathrm{pH}$ of 6.5 , activity reaching $27.07 \mathrm{U} / \mathrm{mL}$ on $5^{\text {th }}$ day. Either increase or decrease beyond the optimum value show decline in enzyme production. However, the mechanism by which the $\mathrm{pH}$ acts on the production pectic enzyme is not known. Piccoli-valle et al., (2001) observed that a high $P G$ and pectin esterase activity was showed by $P$. griseoroseum in more acid $\mathrm{pH}$ of 4.5 and 5 and of pectinlyase, $\mathrm{pH}$ was close to the neutral, 5-7. $P$. viridicatum showed maximum production of polygalacturonase and pectinlyase at a $\mathrm{pH}$ of 4.5 and 5 respectively (Silva et al., 2002). In the present study $P$. chrysogenum exhibited maximum PG production at $35^{\circ} \mathrm{C}(27.21 \mathrm{U} / \mathrm{mL})$ (Fig. 2). The temperature optima of by Sepahdex G-100 column chromatography. It showed an increased specific activity of $P$. chrysogenum pectinase to $145.84 \mathrm{IU} / \mathrm{mg}$ protein and enzyme recovery of $48.12 \%$ (Table1.). Preparations of the enzyme obtained from culture filtrates of $P$. italicum were subjected to ion exchanger DEAE-cellulose and carboxymethyl cellulose chromatography at $\mathrm{pH} 8$ and 6 , respectively. The preparations yielded the elution $\mathrm{pH}$ value of 8.6 and the elution volume of $15.1 \mathrm{~mL}$ and about three-fold higher specific activity (Alana et al., 1990).

\section{Enzyme characterization}

The pectinase activity of $P$. chrysogenum was found to be highest at pH 6.5 using sodium citrate buffer (Fig. 4). Marcia et al., (1999) studied the stability of PG against $\mathrm{pH}$. Their results indicated that the enzyme was stable in a $\mathrm{pH}$ range of 6-8 and showed highest activity at $\mathrm{pH} 6$. Martin et al., (2004) reported that PG from Penicillium sp. was stable at $\mathrm{pH}$ range of $3-8$ and maintained $70 \%$ of initial activity at $70^{\circ} \mathrm{C}$. $\mathrm{PL}$ produced by this microorganism was stable in acidic to neutral $\mathrm{pH}(4-8)$ and was stable in temperature lower than $40^{\circ} \mathrm{C}$.

The optimum temperature that showed highest enzyme activity for $P$. chrysogenum was $50^{\circ} \mathrm{C}$ (Fig. 5). Alana et al., (1990) reported that the temperature effect on $P$. italicum $\mathrm{PL}$ activity consisted of an increase up to $50^{\circ} \mathrm{C}$. PL from $P$. italicum was more thermostable than 
other pectin lyases described for Penicillium culture filtrates. The pectinase enzyme produced by $P$. chrysogenum was stable up to $60 \mathrm{~min}$ and showed maximum activity (Fig. 6). Denis et al., (2002) reported a similar result with polygalacturonase produced by Penicillium viridicatum exhibited maximal activity and was stable at $\mathrm{pH} 5-8$ and maintained $80 \%$ of its activity at $\mathrm{pH}$ 9. Pectin lyase was more sensitive to $\mathrm{pH}$ variation, presenting maximum stability at $\mathrm{pH}$ 3.5-4.5 which declined to $80 \%$ at $\mathrm{pH} 5$ and to $60 \%$ at $\mathrm{pH} 6$.
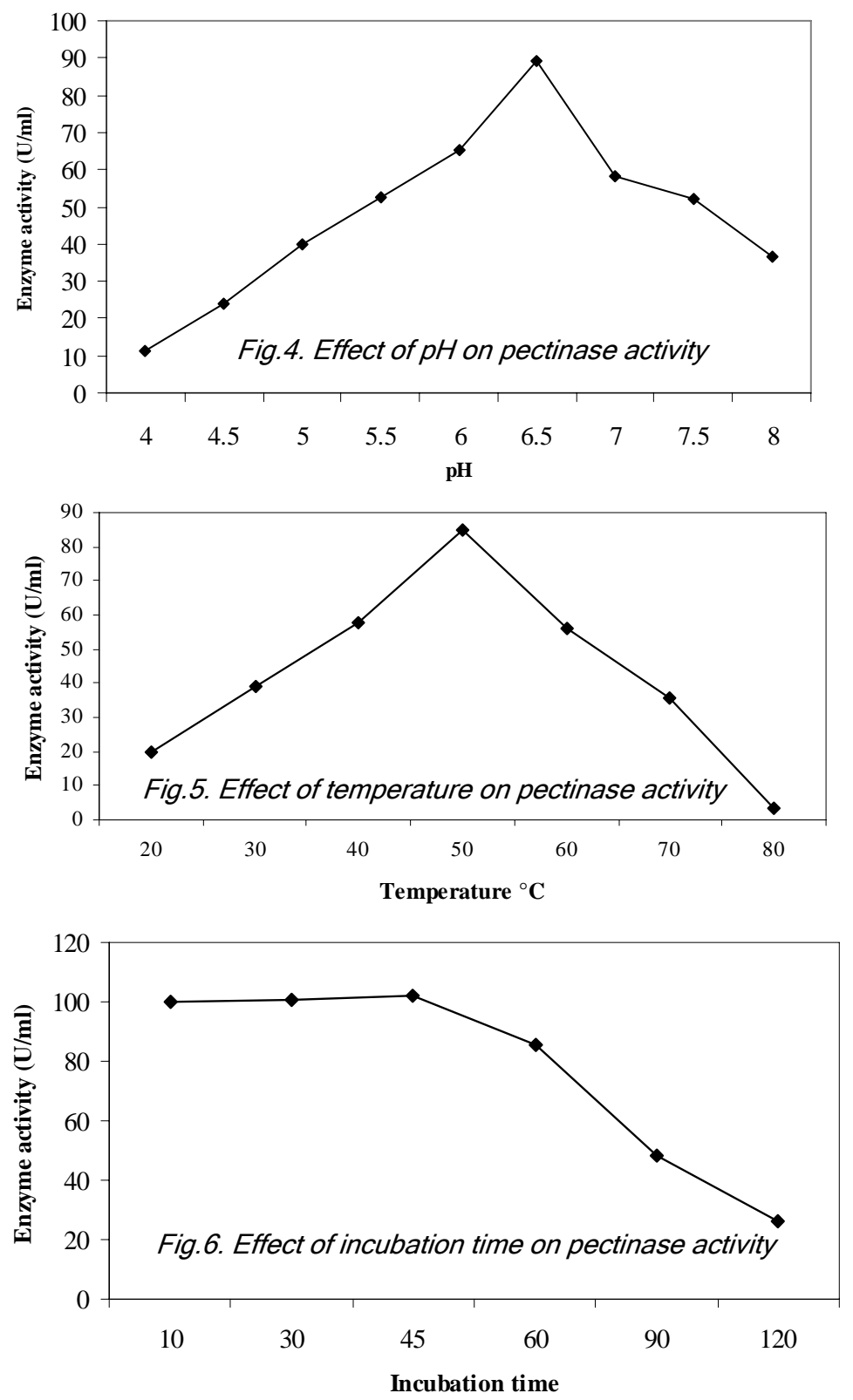

The kinetic parameter of purified pectinase enzyme from $P$. chrysogenum was determined. The pectinase enzyme from $P$. chrysogenum showed a $\mathrm{V}_{\max }$ of $85 \mathrm{U} / \mathrm{mg}$ protein and $\mathrm{K}_{\mathrm{m}}$ of $1 \mathrm{mg} / \mathrm{mL}$ (Table 2.). Sohel et al., (2007) reported that the $V_{\text {max }} / \mathrm{K}_{\mathrm{m}}$ values of pectinase enzyme were increased from 11 to 14 . Among the metal ions tested, addition of $5 \mathrm{mM} \mathrm{CaCl} 2$ enhanced the activity of pectinase enzyme produced by $P$. chrysogenum by $3.56 \% . \mathrm{MgCl}_{2}$ and $\mathrm{ZnCl}_{2}$ inhibited pectinase enzyme activity to the level of 21.2 and $14.8 \%$. Similarly $\mathrm{HgCl}_{2}$, $\mathrm{CoCl}_{2}$ and $\mathrm{CuSO}_{4}$ have been reported to inhibit activity of pectinase of $\quad P$. chrysogenum up to $60 \%$. $\mathrm{BaCl}_{2}$ and EDTA exhibited maximum inhibition of $40 \%$ on pectinase enzyme activity (Table 3.). Alana et al., (1990) reported that $\mathrm{Ca}^{2^{+}}, \mathrm{Mg}^{2^{+}}, \mathrm{Zn}^{2^{+}}$and $\mathrm{Mn}^{2^{+}}$did not affect pectin lyase activity of $P$. italicum at $5 \mathrm{mM}$, while $\mathrm{Co}^{2^{+}}$ reduced it by $14 \%$. However $\mathrm{Cu}^{2^{+}}$and $\mathrm{Fe}^{2^{+}}$at the same concentration produced complete inhibition. When a chelating agent (ethylene dinitrilotetra aceticacid) was added at $0.2 \mathrm{mM}$ to the incubation mixture, pectin lyase activity was not affected.

Optimal activity was observed at $0.05 \mathrm{mM}$ of $\mathrm{CaCl}_{2}$, although the enzyme produced by Clostridium stercorarium was more or less activated throughout a range of $\mathrm{CaCl}_{2}$ concentrations from 0.05 to $0.2 \mathrm{mM}$. The addition of $0.2 \mathrm{mM}$ EDTA inhibited activity to less than $5 \%$ of maximum (Hla et al., 2005).

The pectinase enzyme produced by $P$. chrysogenum showed a molecular weight of $31 \mathrm{kDa}$ (Fig. 7). The molecular mass of $P$. italicum $(22 \mathrm{kDa})$ pectin lyase was lower than those reported for the enzyme isolated from a fungal source $(30-35 \mathrm{kDa})$. A pectin lyase with a molecular mass of $18.2 \mathrm{kDa}$ has been found in culture filtrates of Botrytis cinerea (Alana et al., 1990).

The properties of pectinase enzyme produced by $P$. chrysogenum were determined. The results revealed that the pectinase enzyme of $P$. chrysogenum can tolerate high temperature and neutral $\mathrm{pH}$ (Table 2.).

\section{Conclusion}

Pectinase enzyme was isolated from the native strain, $P$. chrysogenum that can be used for various industrial applications including extraction and clarification of fruit juices, processing of cotton fabric in textile industries, bleaching of paper, removal of pectic waste waters and maceration of tea leaves.

\section{Acknowledgements}

The authors are sincerely grateful to the management, Karpagam University, Coimbatore, Tamil Nadu, India for encouragement and support.

\section{References}

1. Alana A, Alkorta I, Dominguez JB, Llama MJ and Serra JL (1990) Pectin lyase activity in a Penicillium Italicum strain. Appl. Envt. Microbiol. 56, 3755-3759.

2. Alkorta I, Garbisu C, Llama MJ and Serra JL (1998) Industrial applications of pectic enzymes: a review. Proc. Biochem. 33, 21-28.
Banu et al. Indian J.Sci.Technol. 
3. Angayarkanni J, Palaniswamy $\mathrm{M}$ Murugesan $\mathrm{S}$ and Swaminathan $\mathrm{K}$ (2002) Improvement of tea leaves fermentation with Aspergillus spp. pectinase. J. Biosci. Bioengg. 94, 299-303.

4. Bruhlmann F, Kim KS, Zimmerman W and Fiechter A (1994) Pectinolytic enzymes from actinomycetes for the degumming of ramie bast fibers. Appl. Envt. Microbiol. 60, 2107-2112.

5. Cardoso PG, Queiroz MV, Pereira $\mathrm{OL}$ and Araújo EF (2007) Morphological and molecular differentiation of the pectinase producing fungi Penicillium expansum and Penicillium griseoroseum. Braz. J. Microbiol. 38, 71-77.

6. Chadha R, Kumbhar BK and Sarkar BC (2003) Enzymatic hydrolysis of carrot for increased juice recovery. $J$. Food Sci. Technol. 40, 35-39.

7. Chellegatti MASC, Fonseca MJV and Said S (2002) Purification and partial characterization of exopolygalacturonase I from Penicillium frequentans. Microbiol. Res.157, 19-24.

8. Dalal S, Sharma A and Gupta MN (2007) A multipurpose immobilized biocatalyst with pectinase, xylanase and cellulase activities. Chem. Central J.16, 1-5.

9. Dominguez H, Nunez MJ and Lema JM (1994) Enzymatic pretreatment to enhance oil extraction from fruits and oil seeds: A review. Food Chem. 49, 271-286.

10. Fawole OB and Odunfa SA (1992) Pectolytic moulds in Nigeria. Lett. Appl. Microbiol. 15, 266-268.

11. Hla SS, Kurokawa J, Suryani Kimura T, Ohmiya K and Sakka K (2005) A novel thermophilic pectate lyase containing two catalytic modules of Clostridium stercorarium. Biosci. Biotechnol. Biochem. 69, 21382145.

12. Jacob $N$ and Prema $P$ (2006) Influence of mode of fermentation on production of polygalacturonase by a novel strain of Streptomyces lydicus. Food Technol. Biotechnol. 44, 263-267.

13. Kashyap DR, Vohra PK, Chopra S and Tewari R (2001) Applications of pectinases in the commercial sector: A review. Bioresour. Technol. 77, 215-227.

14. Laemmli UK (1970) Cleavage of structural proteins during the assembly of the head of bacteriophage T4. Nature. 227, 680-685.

15. Lineweaver $\mathrm{H}$ and Burk $\mathrm{D}$ (1934) The determination of enzyme dissociation constants. J. Am. Chem. Soc. 56, 658-666.

16. Lowry $\mathrm{OH}$, Rosebrough $\mathrm{NJ}$, Farr $\mathrm{AL}$ and Randall RJ (1951) Protein measurement with folin phenol reagent. J. Biol. Chem. 193, 265-275.

17. Malvessi E and Silveira MM (2004) Influence of medium composition and $\mathrm{pH}$ on the production of polygalacturonases by

Aspergillus oryzae. Braz. Arch. Biol. Technol. 47, 693-702.

18. Martin N, Souza SR, Silva R and Gomes E (2004) Pectinase production by fungal strains in solid state fermentation using agro-industrial bioproduct. Braz. Arch. Biol. Technol. 47, 813-819.

19. Mellon JE and Cotty PJ (2004) Expression of pectinase activity among Aspergillus flavus isolates from southwestern and southeastern United States. Mycopathologia.157, 333-338.

20. Miller GL (1959) Use of Dinitrosalicylic acid for determination of reducing sugar. Anal. Chem. 31, 426-428.

21. Pericin DM, Madarev SZ, Radulovic LM and Skrinjar M (2007) Production of exopectinase by Penicillium roqueorti using pumpkin oil cake. Nat. Sci. 113, 313-320.

22. Phutela U, Dhuna V, Sandhu S and Chadha BS (2005) Pectinase and polygalacturonase production by a thermophilic Aspergillus fumigatus isolated from decomposting orange peels. Braz. J. Microbiol. 36, 63-69.

23. Piccoli-valle RH, Passos FML, Passos FJV and Silva DO (2001) Production of pectin lyase by Penicillium griseoroseum in bioreactors in the absence of inducer. Braz. J. Microbiol. 32,135-140.

24. Silva D, Martins ES, Silva R and Gomes E (2002) Pectinase production by Penicillium viridicatum RFC3 by solid state fermentation using agro-industrial by-products. Braz. J. Microbiol. 33, 318-324.

25. Soares MMCN, Silva R and Gomes E (1999) Screening of bacterial strains for pectinolytic activity: characterization of the polygalacturonase produced by Bacillus species. Rev. Micobiol. 30, 229-303.

26. Solbak Al, Richardson TH, McCann RT, Kline KA, Bartnek F, Tomlinson G, Tan X, Parra-Gessert L, Frey GJ, Podar M, Luginbuhl P, Gray KA, Mathur EJ, Robertson DE, Burk MJ, Hazlewood GP, Short JM and Kerovuo J (2005) Discovery of pectin degrading enzymes and directed evolution of a novel pectate lyase for processing cotton fabric. J. Biol. Chem. 280, 9431-9438.

27. Torres EF, Sepulveda TV and Gonzalez GV (2006) Production of hydrolytic depolymerising pectinases. Food. Technol. Biotechnol. 44, 221-227. 